\title{
Impacts of Scour on Lateral Pile Behavior in the Marine Environment
}

\author{
Yasser El Sayed I. Mostafa \\ Professor of Harbor Engineering and Marine Structures, Dept. of Irrigation \& Hydraulics \\ Faculty of Engineering, Ain Shams University, Cairo, Egypt, \\ Email: yasser_mostafa@eng.asu.edu.eg
}

\begin{abstract}
Piles supporting marine structures are subjected to lateral loads due to berthing, mooring forces, waves and current forces. Scour around piles can have significant impact on the lateral loading capacity and hence affect the stability of marine structures. This paper presents the impact of scour on lateral loading of single piles and pile groups installed in coheshionless soils. Finite element modeling and Winkler model were used in the analyses. Different parameters were considered such as scour depth, magnitude of lateral load, pile group arrangement, pile spacing, pile slenderness ratio and pile batter angle. The results showed that global scour has greater impact on lateral pile capacity compared to local scour. Scour has greater impact on lateral loading of pile groups compared to its impact on single piles. Pile groups with side-by-side arrangement exposed to scour are more critical than single piles and piles groups with tandem arrangement due to the combined effect of scour and pile-soil-pile interaction. Some recommendations for scour protection are provided based on pile group arrangement, pile spacing and slenderness ratio
\end{abstract}

Key Words: Piles, marine structures, lateral loading, scour

\section{INTRODUCTION}

Marine structures such as jetties, seawalls, relieving platforms, quay walls and fixed offshore (jacket type) structures are often supported on pile groups. These piles are usually subjected to large lateral loads induced from waves, currents, vessel berthing and mooring forces. Piles in the marine environment are subjected to scour due to waves, current and ship propeller jets. The scour can significantly reduce the lateral pile capacity and could lead to the failure of marine structures supported on piles.

Numerous publications are found in the literature for investigating the scour around piles for bridge piers and a smaller number of publications investigating the scour around marine structures. Moreover, a very limited number of publications regarding the effect of scour on the behavior of single piles and pile groups is found in the literature. A very limited number of publications regarding the effect of scour on the behavior of piles are found in the literature. A thorough review of available literature on the topic showed that there is no research related to full-scale field or lab tests on scour effects on laterally loaded piles in sand.

Effect of scour on lateral loading of single piles has been investigated in a few recent publications such as Kishore et al. [6], Lin et al. [7], Mostafa [9] and Ni et al. [11]. Mostafa [9] reported that scour has significant impact on single piles installed in sand and less significant impact on piles installed in clay.

Effect of scour on the behavior of pile groups has been investigated in a very few recent publications (e.g. Mostafa [10]).

As piles are usually installed in groups, it becomes necessary to study the effect of scour on the behavior of pile group not just single piles. The combination of scour and pile-soil-pile interaction (i.e., group effect) can lead to a significant reduction in lateral pile capacity and consequently may lead to the failure of marine structures.

This paper presents the impact of scour on lateral behavior of single piles and pile groups installed in coheshionless soils. Different parameters were considered such as local and global scour, scour depth, magnitude of lateral load, arrangement of pile groups, spacing between piles, pile slenderness ration and pile batter angle.

For single piles, Finite element model (FEM) using the software program PLAXIS and Winkler model using the software program LPILE were used in the analysis.

For pile groups, the software program GROUP [4] was used in the analysis. GROUP is a 3D software program for analyzing pile groups subjected to axial and lateral loads. A solution requires iteration to accommodate the nonlinear response of each pile in the group model. The program GROUP solves the nonlinear response of each pile under combined loadings. For closely-spaced piles, the pile-soil-pile interaction is taken into account by introducing reduction factors for the p-y curves used for each single pile. These reduction factors or called "p-multipliers" are generated based on results of laboratory and field experiments published in the literature.

Validation of the numerical modeling conducted using the programs LPILE and GROUP were conducted through comparisons with experimental results. More details can be found in Mostafa [9] and Mostafa [10] 


\section{Scour around Piles in the Marine Environment}

Piles supporting coastal and marine structures are subjected to scour due to waves, currents and ship propeller jets. A summary of the expected scour depth due to these causes is provided in the following subsections.

\subsection{Scour due to Waves and Current}

It has been documented that local scour depth in sandy soils (ds) due to current only is 1.3 times pile diameter (d) with a mean of 0.7 . In other words, the maximum scour depth is about 2 times the pile diameter (i.e., ds/d=2). Some experimental research has been performed to examine the scour around pile groups due to waves and currents. Sumer and Fredsøe [12] examined the wave scour around a group of closely spaced piles. Sumer et al. [13] investigated the global and local scour at pile groups exposed to steady currents. Mostafa and Agamy [8] examined the combined effect of waves and current on a group of closely and widely spaced piles. Scour depth to pile diameter ratio (ds/d) due to waves only can be as high as 1 for Keulegan-Carpenter number (KC) of 13. For pile groups exposed to currents only, total scour (global scour and local scour) increases with the increase in number of piles. The scour depth to pile diameter ratio (ds/d) can be as high as $2.6[13]$.

\subsection{Scour due to Ship Propeller Jets}

During berthing or de-berthing operations, a ship is in proximity to harbor structures and erosion may occur around piles supporting jetties or relieving platforms and sloping riprap [16]. Figure 1 shows a sketch of scour around piles supporting jetties or relieving platforms due to ship propeller jets. It is noticed that scour at the front (leading) pile is larger than that at the trailing (aft) pile. If pile spacing increases, scour at the trailing pile decreases as a result of the deposition of scoured sediment taking place at the vicinity of the front pile as can be seen in Figure 1. Experimental results of Yuksel et al. [16] indicated that maximum scour depth to pile diameter ratio (ds/d) is about 2.25.

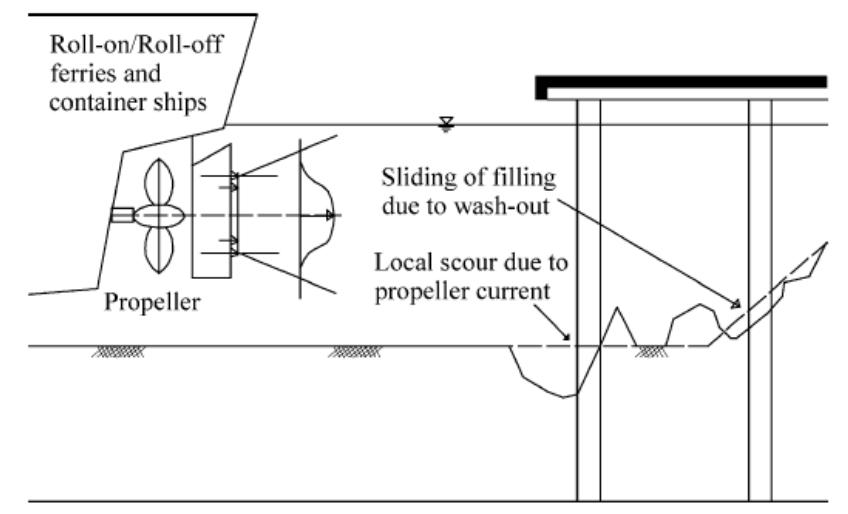

Figure 1. Erosion of seabed due to ship propeller jets (Chin et al., 1996 [3])

\section{Impact of Scour on Single Piles}

The effect of scour on single piles was investigated. In the analysis, all piles were assumed to be steel piles with outside diameter (d) of $0.5 \mathrm{~m}$, total pile length (L) of $30 \mathrm{~m}$ and cross section area (A) of $0.01944 \mathrm{~m} 2$. The soil was assumed to be medium dense sand with angle of friction $(\phi)$ of 350 and soil unit weight $(\gamma \mathrm{s})$ of $17 \mathrm{kN} / \mathrm{m} 3$.

\subsection{Effect of Local and Global Scour}

Effect of local and global scour around single piles installed in sandy soils was investigated. Scour hole due to local scour was modeled using PLAXIS. Scour hole depth equivalent to twice the pile diameter was considered $(\mathrm{ds} / \mathrm{d}=2)$. Global scour was modeled through removing the soil layer of thickness equal to twice the pile diameter. Local scour represents the case of scour hole around pile. The hole was modeled in PLAXIS as conical shape with trapezoidal cross section assuming scour depth equal to $2 \mathrm{~d}$ and the scour hole base extends around the pile at a distance (Lsb) varying between 0 and $\mathrm{d}$. The hole side slope was assumed to be 45o. Different lateral loads were applied at the pile head. Global scour was modeled in PLAXIS and LPILE. It should be noted that local scour with different hole dimensions can not be modeled by LPILE [5] 
Figure 2 shows the normalized pile head displacement (y/d) versus lateral load at pile head for case of no scour, global scour and local scour with different scour hole dimensions. No significant difference was found if lateral load (F) is lower than $100 \mathrm{kN}$. For higher lateral loads, the difference becomes more considerable as pile-soil system behaves nonlinearly.

Ultimate lateral pile capacity when scour is neglected was found to be $1100 \mathrm{kN}$. The ultimate lateral pile capacity if local scour hole base (Lsb) equals 0 and d was found to be $1000 \mathrm{kN}$ and $700 \mathrm{kN}$, respectively. For case of global scour $(\mathrm{Lsb}=\infty)$, ultimate lateral pile capacity was calculated to be $500 \mathrm{kN}$, which is about $45 \%$ of the ultimate capacity if scour is neglected. Ultimate lateral pile capacity in case of global scour is about $50 \%$ to $70 \%$ of that in case of local scour depending on the scour hole dimensions. For case of global scour, it was noted that results using PLAXIS and LPILE agree reasonably.

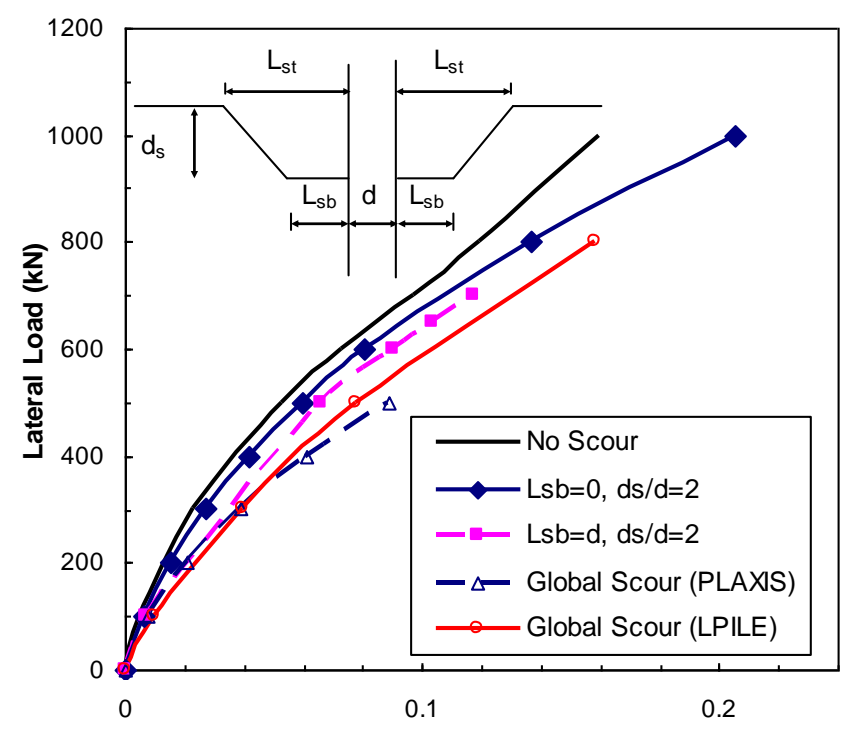

Normalized Pile Head Displacement (y/d)

Figure 2 Normalized pile head displacement versus lateral load for case of no scour, global scour and local scour with different scour hole dimensions

\subsection{Effect of Scour Depth}

A parametric study was conducted to investigate the effect of scour depth in lateral behavior of single steel pipe piles. A relative scour depth (ds/d) of 1, 1.3, 2 and 3 was selected. Figures 3 and 4 presents lateral displacement and bending moment along pile length, respectively. For the same lateral load of $100 \mathrm{kN}$, lateral pile head displacement increases significantly with the increase in scour depth. For $\mathrm{ds} / \mathrm{d}=1,1.3,2$ and 3 , the maximum pile head displacement increases compared to the case of no scour by about $37 \%, 51 \%, 87 \%$ and $155 \%$, respectively.

For case of $\mathrm{ds} / \mathrm{d}=2$, bending moment at pile head increases by about $48 \%$ compared to that for pile without scour. Also, maximum bending moment along pile length increases by about $60 \%$ over that for case of no scour. Location of maximum bending moment occurs at a deeper depth when scour depth increases. For a pile without scour, maximum bending moment is located at about 6 pile diameters (6d). For a pile with scour equivalent to twice the pile diameter $(\mathrm{ds} / \mathrm{d}=2)$, maximum bending moment is located at about $7.2 \mathrm{~d}$. The increase in bending moment due to scour can require piles with larger pile rigidity or higher steel grade to ensure that bending stresses do not exceed the pile yield stress. 


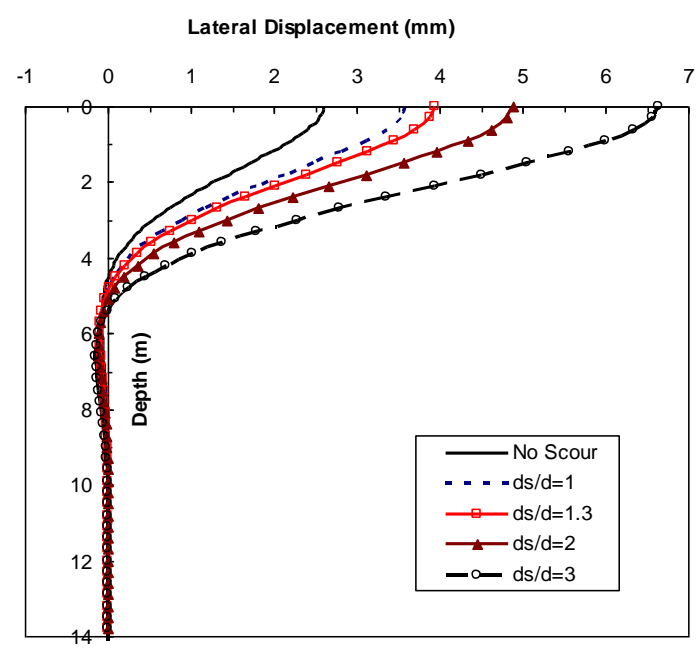

Figure 3 Effect of scour depth on lateral displacement along pile length, $(\mathrm{F}=100 \mathrm{kN})$

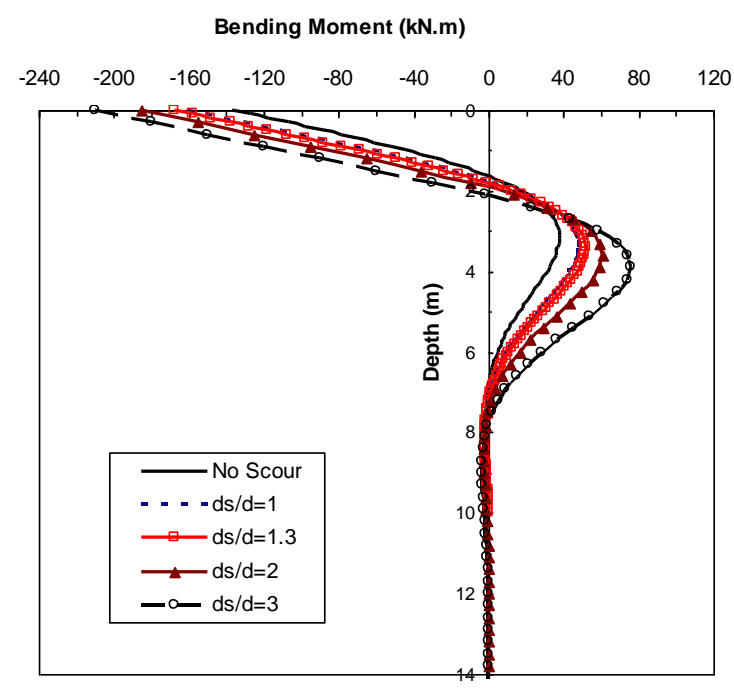

Figure 4 Effect of scour depth on bending moment along pile length, $(\mathrm{F}=100 \mathrm{kN})$

\section{Impact of Scour on Pile Groups}

The effect of scour on pile groups was investigated. For sake of comparison, pile and soil data for the case of single piles were also assumed for the pile groups. The pile spacing to diameter ratio (S/d) was taken to be 3 . The length to diameter ratio $(\mathrm{L} / \mathrm{d})$ was assumed to be 60 so that pile embedment length has no impact on the results.

\section{1. $\quad$ Effect of Pile Arrangement}

The analysis considered two main pile groups. The pile groups were assumed to be arranged side-by-side (i.e., $\theta=90 \mathrm{o}$ ) or tandem arrangement (i.e., $\theta=0 \mathrm{o}$ ) where $\theta$ is the angle between the lateral load and the line connecting the two piles and $S$ is the centre line to centre line spacing between piles. Figure 5 shows a general sketch indicating a pile location within a pile group subjected to lateral loading. The piles were assumed to be spaced three times the pile diameter (i.e., $\mathrm{S} / \mathrm{d}=3$ ). Pile-soil-pile interaction was considered in the analysis. The reduction factors generated in the program GROUP [4] were used in this study. 


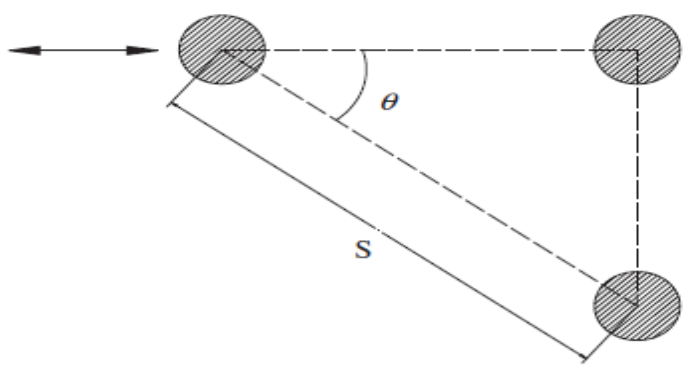

Figure 5. The location of a pile in pile group under lateral loading

Figure 6 shows the effect of normalized scour depth $(\mathrm{ds} / \mathrm{d})$ on the lateral capacity of a group of two piles with side-by-side arrangement and tandem arrangement. Figure $6 \mathrm{~b}$ indicates that the reduction in pile group capacity of groups with side-by-side arrangement is higher than that for groups with tandem arrangement. A relatively small scour depth $(\mathrm{ds} / \mathrm{d}=1)$ leads to a reduction in lateral group capacity ranging between about $12.5 \%$ and $15 \%$ for piles with tandem arrangement and side-by-side arrangement, respectively. A scour depth of three pile diameter (i.e., ds/d=3) causes a reduction in the lateral group capacity ranging between $29 \%$ and $35 \%$ for piles with tandem arrangement and side-by-side arrangement, respectively. The rate of reduction in lateral group capacity if ds/d varies between 0 and 1 is slightly higher than that if $\mathrm{ds} / \mathrm{d}$ is between 1 and 3 .

Figure 7 shows load-displacement curves for groups of two piles with tandem arrangement $(\theta=0 \mathrm{o})$ and side-byside arrangement $(\theta=90 \mathrm{o})$ neglecting and considering scour. Load-displacement curves for single pile computed using program LPILE were plotted for comparison. It can be seen that the load-displacement curve for single pile is very similar to that for two piles with side-by-side arrangement. This is because the side-by-side reduction factor due to group interaction is negligible if the spacing is greater than three times the pile diameter [GROUP] [4]. For the same lateral loading, pile group with tandem arrangement has less displacement than that for pile group with side-by-side arrangement. For relatively small lateral loads on the group $(\mathrm{F}<100 \mathrm{kN})$ no major differences in the normalized pile head displacement $(y / d)$ are found due to pile group arrangement. The impact of pile arrangement is more pronounced with the increase in lateral loading due to the nonlinearity in the pile-soil system. For single pile and pile groups with different arrangements, scour increases the pile head displacement. For the same lateral loading, piles with tandem arrangement even when scour is considered has lower displacement than the piles with side-by-side arrangement with no scour. This is due to the greater reduction in group efficiency for side-by-side arrangement compared to the reduction in group efficiency for tandem arrangement.

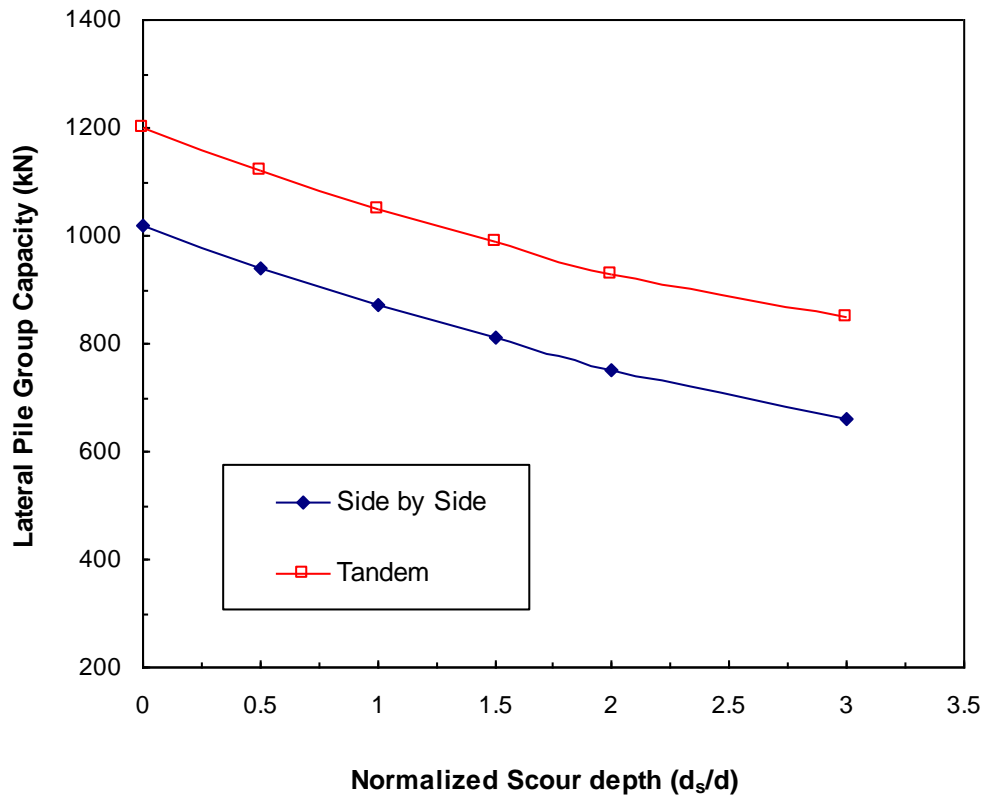

a) 


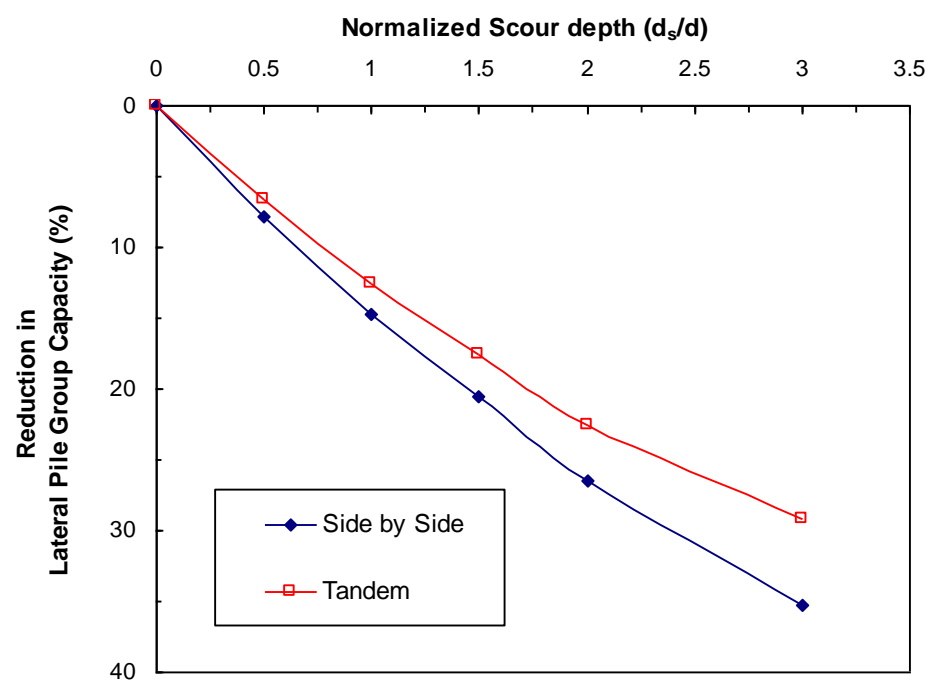

b)

Figure 6. Relationship between normalized scour depth and lateral pile capacity ( $\mathrm{S} / \mathrm{d}=3, \mathrm{~L}=30 \mathrm{~m}, \mathrm{~L} / \mathrm{d}=60$ )



Figure 7. Load-displacement curves for single pile and pile groups with different arrangement neglecting and considering scour $(\mathrm{S} / \mathrm{d}=3, \mathrm{~L}=30 \mathrm{~m}, \mathrm{~L} / \mathrm{d}=60)$

Figure 8 shows lateral displacement and bending moment along pile length when a group of two piles is subjected to lateral load $(\mathrm{F})$ of $200 \mathrm{kN}$. For the sake of comparison, single pile subjected to lateral load of $100 \mathrm{kN}$ was computed and plotted. It is noted that displacement of piles with side-by-side arrangement $(\theta=90 \mathrm{o})$ is higher than that for single pile and pile group with tandem arrangement $(\theta=0 \mathrm{o})$. Scour depth of twice pile diameter increases the head displacement of pile group with side-by-side arrangement from $7.4 \mathrm{~mm}$ to $18 \mathrm{~mm}$ (i.e, increase by about $114 \%$ ). For piles with tandem arrangement, the displacement at pile head increases due to scour from about $3.4 \mathrm{~mm}$ to $6.5 \mathrm{~mm}$ (i.e., increase by about $91 \%$ ). For the single pile, scour increased the pile head displacement from about $2.6 \mathrm{~mm}$ to about 4.9 $\mathrm{mm}$ (i.e, increase by about $88 \%$ ). Under the same loading conditions, the displacement of pile group is higher than that for single pile. This is attributed to the pile-soil-pile interaction. The scour effect on pile group with side-by-side arrangement is more significant than that for single piles and pile group with tandem arrangement. The bending moment for piles with side-by-side arrangement is larger than that for single pile and pile group with tandem arrangement. 


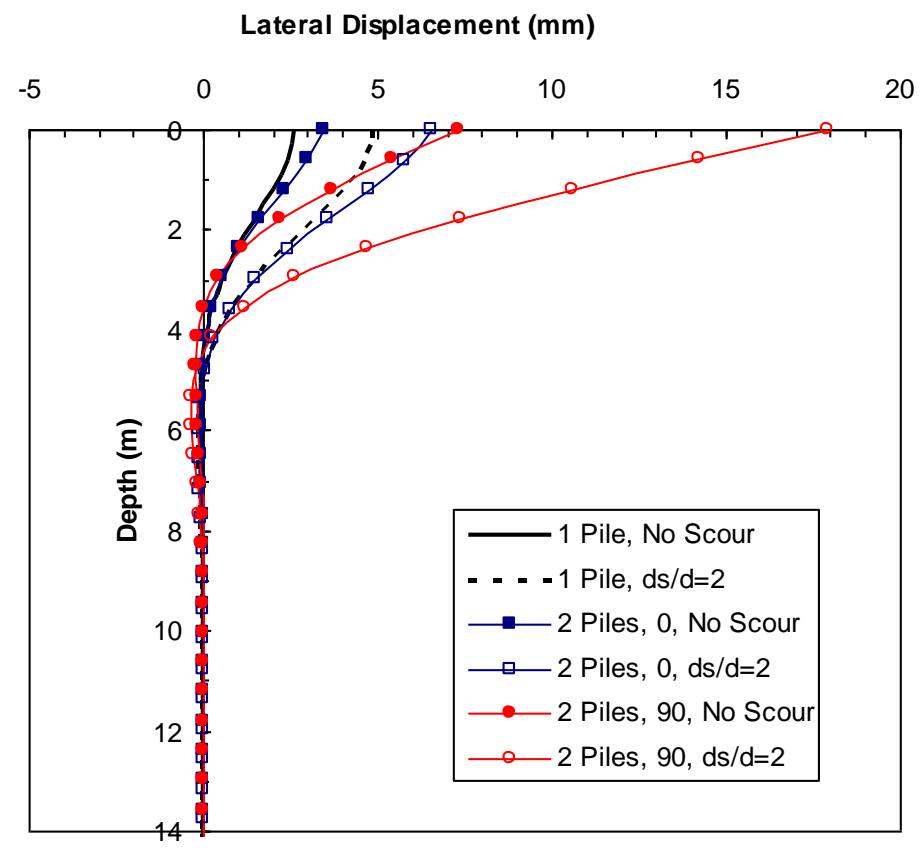

a)

Bending Moment (kN.m)

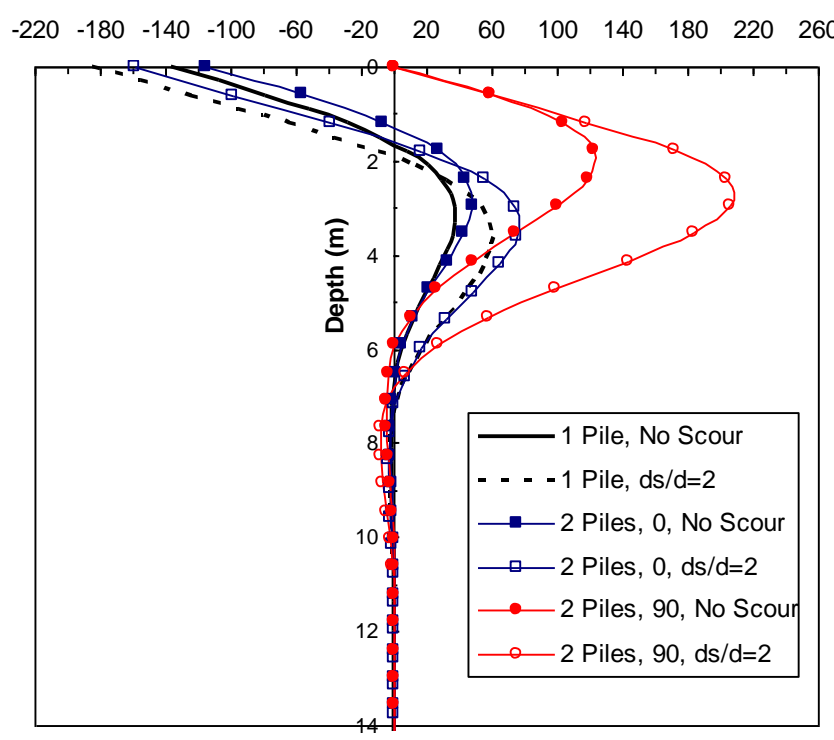

b)

Figure 8. Effect of pile arrangement on lateral response along pile length, a) lateral displacement, b) bending moment $(\mathrm{F}=200 \mathrm{kN}, \mathrm{S} / \mathrm{d}=3, \mathrm{~L}=30 \mathrm{~m}, \mathrm{~L} / \mathrm{d}=60)$ 


\subsection{Effect of Pile Spacing}

The effect of centre line to centre line pile spacing considering pile-soil-pile interaction was evaluated. Spacing to diameter ratio (S/d) of 1, 3 and 5 for pile groups with tandem and side-by-side arrangements was considered. The impact of scour is also investigated.

When piles are closely spaced, the shear failure planes resulting from the movement of each pile will overlap and the ultimate resistance for a pile in a group may be less than that of a single pile. This is called "shadow effect" or "pilesoil-pile interaction" which influences the efficiency of individual piles in a group. Reduction factors generated in the program GROUP [4] were used in this study. These reduction factors are based on many laboratory and field experiments collected from the literature.

Brown et al. [2] introduced the concept of the p-multiplier. This concept represents the response of the group to lateral loading in terms of the response of an assembly of single piles with the soil reaction modeled using $\mathrm{p}-\mathrm{y}$ curves adjusted using a " $p$-multiplier" where $p$ is the lateral soil reaction and $y$ is lateral pile displacement. The p-multiplier assumes a different value that depends on whether a pile is in a leading or in a trailing position and the angle between the line connecting two piles and the load direction.

Figure 9 shows the relationship between normalized scour depth and lateral pile group capacity taking into consideration the reduction in group efficiency due to pile-soil-pile interaction. It is evident that the lateral pile group capacity for the two piles with tandem arrangement is higher than that of the two piles with side-by-side arrangement by about $18 \%$ to $32 \%$. For closely spaced piles (i.e., $\mathrm{S} / \mathrm{d}=1$ ) the group capacity is reduced by about $11 \%$ and $5 \%$ for case of side-by-side arrangement and tandem arrangement respectively. A scour depth equivalent to three times pile diameter decreases the lateral group capacity by about $32 \%$ to $35 \%$ for groups with side-by side arrangement. The same scour depth reduced the capacity by about $27 \%$ to $30 \%$ for groups with tandem arrangement.

It should be noted that for tandem arrangement, the ultimate lateral capacity of trailing pile is lower than that of leading pile assuming the scour depth is the same at leading and trailing piles. Therefore, lateral load that causes yield moment of trailing pile was considered in Figure 9.

Figure 10 shows load-displacement curves for two pile group with side-by-side arrangement considering different pile spacing. Impact of scour was also considered by assuming a scour depth equivalent to twice the pile diameter. Figure 10 indicates that pile displacement increases significantly when the piles are closely spaced and scour is considered. As expected, the ultimate group capacity increases with the increase in pile spacing and if scour is neglected. The effect of scour is more pronounced with the increase in lateral loading. As an example, a lateral load of $600 \mathrm{kN}$ on a group with $\mathrm{S} / \mathrm{d}=1$ causes a displacement $(\mathrm{y} / \mathrm{d})$ of 0.11 and 0.23 if scour is neglected and considered, respectively. For the same lateral load applied on a group of widely spaced piles ( $\mathrm{S} / \mathrm{d}=5), \mathrm{y} / \mathrm{d}$ is computed to be 0.074 and 0.17 if scour is neglected and considered, respectively. For the same pile spacing ratio, the displacement increases by about $100 \%$ to $130 \%$ due to scour. If scour is neglected and pile spacing ratio is varied, the displacement increases by about 7\% if S/d is reduced from 5 to 3 and the displacement increases by about 40\% if S/d is reduced from 3 to 1 . This is due to the pile-soil-pile interaction. If scour is neglected, the ultimate lateral group capacity is reduced from $1050 \mathrm{kN}$ if $\mathrm{S} / \mathrm{d}=5$ to $900 \mathrm{kN}$ if $\mathrm{S} / \mathrm{d}=1$. This corresponds to a reduction of about $14 \%$ due to pile-soil-pile interaction. For the same S/d ratio, the ultimate lateral capacity reduces by about $23 \%$ to $29 \%$ due to the scour effect.

Therefore, it is concluded that the effect of scour on lateral group capacity and displacement is more pronounced than the effect of pile-soil-pile interaction.

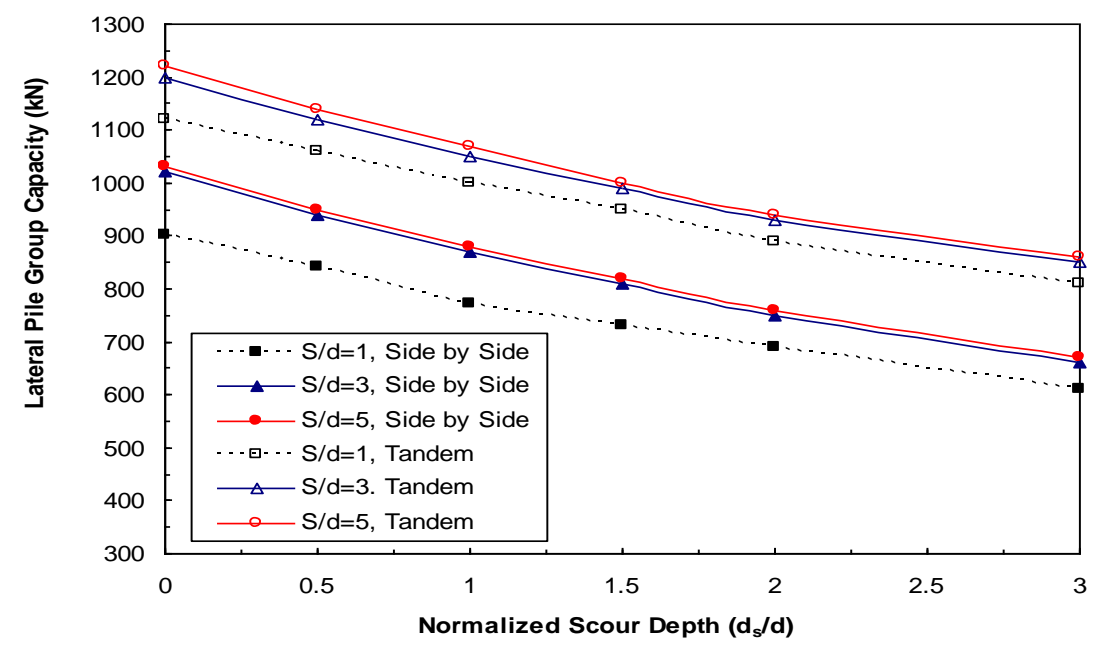

Figure 9. Normalized scour depth versus lateral pile group capacity for different pile spacing and arrangement 


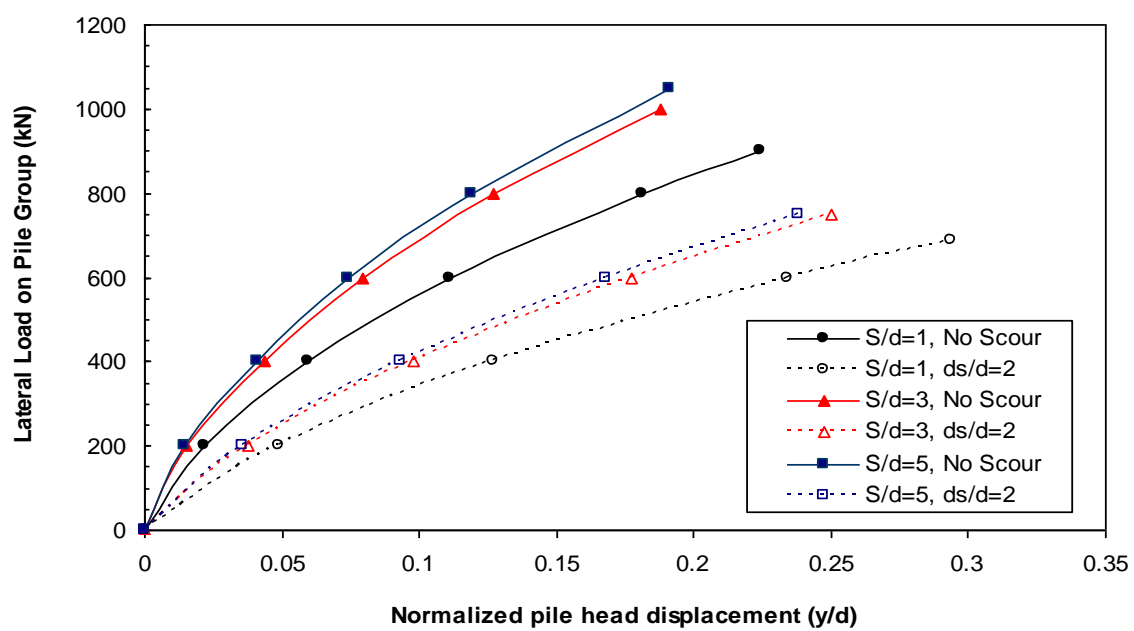

Figure 10. Load-displacement curves for pile group with different pile spacing with and without scour (Side-bySide arrangement, $\mathrm{L} / \mathrm{d}=60$ )

\subsection{Effect of Pile Slenderness Ratio}

Pile length to diameter ratio (slenderness ratio) may be critical for piles supporting coastal structures under scoured conditions. To examine the effect of pile slenderness ratio, L/d ratios of 5, 7.5, 10, 12.5, 15,20 and 40 were considered. Pile slenderness ratio for some dolphins or suction piles may be as low as 5 . The pile spacing ratio (S/d) was kept constant as 3. Groups of two piles with side-by-side arrangement were considered as this is a more critical case than groups with tandem arrangement.

Figure 11 shows the relationship between normalized scour depth and lateral pile capacity for different pile slenderness ratio. It is noted that for $\mathrm{L} / \mathrm{d}=5$, the rate of decrease in lateral pile group capacity between $\mathrm{ds} / \mathrm{d}=0$ to 0.5 is higher than that rate if $\mathrm{ds} / \mathrm{d}$ varies between 0.5 and 3 . For $\mathrm{L} / \mathrm{d}=7.5$ and 10 , the rate of decrease in lateral group capacity between $\mathrm{ds} / \mathrm{d}=0$ and 1 is higher than that rate if $\mathrm{ds} / \mathrm{d}$ varies between 1 to 3 .

It is also noted from Figure 11 that percentage decrease in lateral pile group capacity (PDC) remains almost constant after the pile slenderness ratio is greater than about 12.5. In another meaning, for pile groups exposed to scour, increasing L/d ratio over 12.5 will not add much difference to the group capacity. Accordingly, the decrease in group capacity due to scouring will be more serious for short piles. This is somewhat similar to a conclusion drawn by Ni et al. [11] who concluded that for single piles, PDC values remain almost constant after L/d is greater than 10.

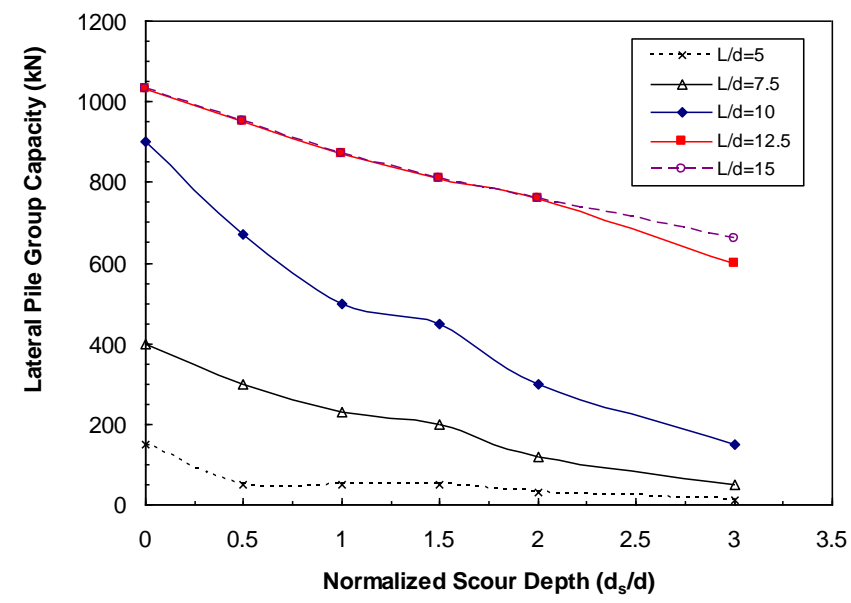

Figure 11. Lateral pile group capacity versus normalized scour depth (ds/d) considering different pile slenderness ratio (L/d) $(\mathrm{S} / \mathrm{d}=3$, Side-by-Side arrangement) 


\subsection{Effect of Pile Batter Angle}

Batter (raked) piles are widely used to support marine structures as they are effective in restricting horizontal displacement of the foundation subjected to large lateral loads or in a liquefied soil flow environment. The disadvantages of such piles are the larger axial forces in the piles [14]. The forces on piles supporting coastal structures are axial vertical loads due to own weight, loads from trucks and cranes and lateral loads from ship impacts, wave loads and mooring forces. The use of batter piles along with vertical piles increases the overall pile group efficiency. Batter piles are classified as positive batter (slip surface deflects upward) and negative batter (slip surface deflects downward) depending on the formation of slip surfaces [15]. Figure 12 illustrates the negative and positive batter piles.

In this paper, the effect of batter angle was investigated. The distance between point of lateral load at the jetty deck and the seabed (i.e, pile free length, Lf) was assumed to be $5 \mathrm{~m}$. This free length is required for vessels berthing and it varies depending on the vessel draft, under keel clearance and distance between sea level and jetty deck level. All pile heads were assumed to be fixed to the jetty deck. The soil was assumed to be medium dense sand with a unit weight $(\square)$ of $17 \mathrm{kN} / \mathrm{m} 3$ and angle of internal friction $(\phi)$ of 350 . The ratio between pile and soil modulus of elasticity (Ep/Es) was assumed to be 2000. In the analysis, two piles were considered; one pile has negative batter and the other one has positive batter. Different batter angles of $0 \mathrm{o}, 5 \mathrm{o}, 10 \mathrm{o}$ and $20 \mathrm{o}$ were investigated.

Figure 13 shows that lateral pile group capacity significantly increases by the increase in batter angle. A batter angle of 50 increases the lateral capacity by about $40 \%$ over vertical piles $(\beta=0)$. The increase in the group capacity is almost linear. The rate of increase in capacity if $\beta$ ranges between $10 \mathrm{o}$ and $20 \mathrm{o}$ is higher than that rate if $\beta$ ranges between $0 \mathrm{o}$ and $10 \mathrm{o}$. If scour depth equivalent to twice pile diameter $(\mathrm{ds} / \mathrm{d}=2)$ is considered, the group lateral capacity decreases by about $5 \%$ to $10 \%$. The rate of change decreases with the increase in batter angle. In another meaning, the scour becomes less significant with the increase in batter angle.



Negative batter pile

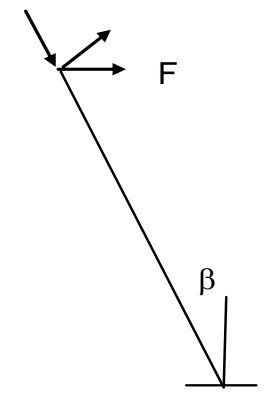

Positive batter pile

Figure 12. Sketch of negative and positive batter piles

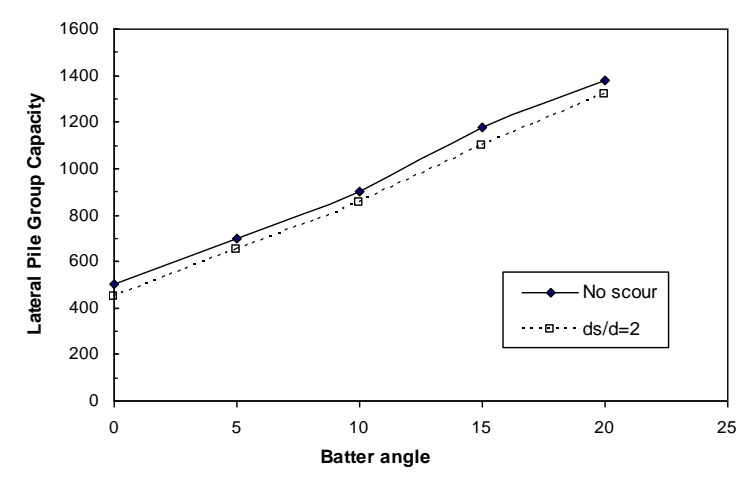

Figure 13. Relationship between pile batter angle and the lateral pile group capacity $(\mathrm{d}=0.5 \mathrm{~m}, \mathrm{~L}=30 \mathrm{~m}, \mathrm{Lf}=5 \mathrm{~m}$, $\mathrm{S} / \mathrm{d}=3$ ) 


\section{Yasser EI Sayed I. Mostafa "Impacts of Scour on Lateral Pile Behavior in the Marine En...”}

\section{Scour Protection}

As discussed in this paper, pile groups subjected to scour due to waves, current and ship propeller jets may be exposed to a scour depth up to 2.6 pile diameter. A value of scour depth to diameter ratio (ds/d) of 2 is often used in practice. It is important for designers and practitioners to know when scour protection around piles supporting coastal structures may be necessary and when it is not.

According to Mostafa and Agamy [8] and Abdeldayem et al. [1], pile groups with side-by-side arrangement causes more scour than groups with tandem arrangement. Scour depth for some cases of pile groups with side-by-side arrangement increases as much as about two times more than its magnitude for the case of single pile according to Mostafa and Agamy [8] and Sumer et al. [13]. Accordingly, for a jetty or berthing structure supported on piles exposed to scour due to ship propeller jets, the leading pile row, which is arranged side-by-side, is expected to suffer more from scour.

From a geotechnical prospective, the ultimate lateral capacity for piles arranged side-by-side is lower than that for piles with tandem arrangement. The side-by-side arrangement is exposed to higher lateral deflections and bending moments. Therefore, the combined effect of scour and pile-soil-pile interaction for closely spaced piles makes the sideby-side arrangement the worst case scenario in terms of significant reduction in pile capacity. This scenario may be even worse if the loading arm or free length (distance between jetty deck level and seabed) is high. In this case, scour protection and frequent monitoring of erosion around the piles may be required.

For raked piles, as scour is less significant when the batter pile angle increases, scour protection is not necessary depending on the required lateral pile capacity.

For short piles, consideration should be given to using scour protection measures such as riprap or geotextile. Alternatively, consideration should be given to increasing the pile length so that the slenderness ratio is at least 12.5 . For already constructed piles with slenderness ratio less than 12.5 , consideration should be given to using a suitable scour protection measure.

It should be noted that this section provides general recommendations on when to use scour protection. The decision to use scour protection around piles should be taken based on the pile, soil and loading conditions.

\section{Conclusions}

Based on numerical modelling of scour around single piles and pile groups installed in medium dense sandy soils, the following conclusions are drawn:

Single Piles:

1. Ultimate lateral capacity for single piles subjected to global scour can be about $45 \%$ of the ultimate lateral capacity of piles without scour.

2. Ultimate lateral capacity for single piles subjected to global scour is found to be about $50 \%$ to $70 \%$ of ultimate lateral capacity of piles subjected to local scour depending on the scour hole dimension.

3. If scour depth ranges between one to 3 pile diameters $(\mathrm{ds} / \mathrm{d}=1$ to 3$)$, the pile head displacement increases by about $37 \%$ to $155 \%$ compared to that for piles without scour.

4. The bending moment in piles with scour increases by about $48 \%$ to $60 \%$ in comparison with the same loading conditions in piles without scouring. The increase in bending moment due to scour can require piles with larger pile rigidity or higher grades to ensure that bending stresses do not exceed the pile yield stress.

Pile Groups:

5. Pile groups with side-by-side arrangement experience higher displacement and bending moments compared to single piles and pile groups with tandem arrangement due to the combined effect of scour depth and pile-soil-pile interaction.

6. The ultimate lateral capacity for pile groups with side-by-side arrangement is lower than that for pile groups with tandem arrangement. For spacing to diameter ratio of 3, a scour depth of three pile diameter (i.e., ds/d=3) causes a reduction in the lateral group capacity ranging between $29 \%$ and $35 \%$ for piles with tandem arrangement and sideby-side arrangement, respectively.

7. The rate of reduction in lateral group capacity if ds/d varies between 0 and 1 is slightly higher than that if ds/d is between 1 and 3 .

8. For relatively small lateral loads on the group $(\mathrm{F}<100 \mathrm{kN})$, no major differences in the normalized pile head displacement $(y / d)$ are found due to the pile group arrangement. The impact of pile arrangement is more pronounced with the increase in lateral loading due to nonlinearity in the pile-soil system.

9. For the same lateral loading, piles with tandem arrangement even when scour is considered has lower displacement than piles with side-by-side arrangement with no scour.

10. The bending moment for piles with side-by-side arrangement is larger than that for single pile and pile group with tandem arrangement. 
11. The effect of scour on lateral group capacity and displacement is more pronounced than the effect of pile-soil-pile interaction.

12. The percentage decrease in lateral pile group capacity (PDC) remains almost constant after the pile slenderness ratio is greater than about 12.5 .

13. A small increase in batter pile angle increases the lateral pile capacity significantly. A batter angle of 5o increases the lateral capacity by about $40 \%$ over vertical piles.

14. Scour depth becomes less significant with the increase in pile batter angle.

15. More attention and consideration should be given to scour protection around piles especially if the piles are closely spaced, arranged side-by-side and if slenderness ratio is less than 12.5 .

\section{REFERENCES}

[1] Abdeldayem, A., Elsaeed, G., and Ghareeb, A, 2011: Effect of Pile Group Arrangements on Local Scour Using Numerical Models. Advances in Natural and Applied Sciences, 5(2), 2011, pp. 141-146.

[2] Brown, D.A., Morrison, C. and Reese, L.C:, 1988: Lateral Load Behavior of Pile Group in Sand. Journal of Geotechnical Engineering, ASCE, 114(11), pp. 1326-1343.

[3] Chin, C., Chiew, Y., Lim, S.Y., and Lim, F.H., 1996: Jet Scour around Vertical Pile. Journal of Waterway, Port, Coastal and Ocean Engineering, 122 (2), pp. 59-67.

[4] Ensoft Inc., GROUP, 2006: A Program for Analyzing a Group of Piles Subjected to Axial and Lateral Loading, Technical Manual, Version 7.0, Austin, Texas.

[5] Ensoft Inc., LPile, 2005: A Program for the Analysis of Piles and Drilled Shafts Under Lateral Loads, Technical Manual, Version 5.0, Austin, Texas.

[6] Kishore, Y.N, S.N. Rao and J.S. Mani, J., 2009: The Behaviour of Laterally Loaded Piles Subjected to Scour in Marine Environment, KSCE Journal of Civil Engineering. Vol. 13, No. 6, pp. 403-406.

[7] Lin, C., Bennett, C., Han, J. and Parsons, R.L, 2010: Scour Effects on the Response of Laterally Loaded Piles Considering Stress History of Sand, Computers and Geotechnics, ElSevier, 37, pp. 1008-1014.

[8] Mostafa, Y.E. and Agamy, A.F, 2011: Scour around Single Pile and Pile Groups Subjected to Waves and Currents, International Journal of Engineering Science and Technology (IJEST). Vol. 3, No. 11, pp. 8160-8178.

[9] Mostafa, Y.E, 2012: Effect of Local and Global Scour on Lateral Response of Single Piles in Different Soil Conditions, Engineering, Scientific Research Publishing, 4, 297-306.

[10] Mostafa, Y.E., 2012(b) "Design considerations for pile groups supporting marine structures with respect to scour, Engineering, Scientific Research Publishing, 4, 833-842.

[11] Ni, S., Huang, Y. and Lo, L., 2012: Numerical Investigation of the Scouring Effect on the Lateral Response of Piles in Sand, J. Perform. Constr. Facil., 26(3), pp. 320-325.

[12] Sumer, B.M, and.Fredsøe, J, 1998: Wave scour around group of vertical piles," Journal of Waterway, Port, Coastal and Ocean Engineering, ASCE, 124 (5), 1998, pp. 248-255.

[13] Sumer, B.M, Bundgaar, K., and J. Fredsøe,J., 2005: Global and Local Scour at Pile Groups, Proceedings of the Fifteenth International Offshore and Polar Engineering Conference, Seoul, Korea, pp. 577-583.

[14] Tazohl, T., Sato, M., Jang, J. and Gazetas, G.,2008: Centrifuge Tests on Pile Foundation-Structure Systems Affected by Liquefaction-Induced Soil Flow after Quay Wall Failure," The 14th World Conference on Earthquake Engineering, Beijing, China.

[15] G. P. Tschebotarioof, G.P, 1953: The Resistance to Lateral Loading of Single Piles and Pile Groups, Special Publication No. 154, ASTM, 1953, West Conshohocken, Pa., pp. 38-48

[16] Yuksel, A., Celikoglu, Y., ECevik, E. and Yuksel, Y., 2005: Jet Scour around Vertical Piles and Pile Groups, Ocean Engineering, 32, 2005, pp. 349-362. 